\title{
EDITORIAL
}

nature

cell biology

\section{Embryonic stem cell development(s)}

Embryonic stem cells are occupying the minds of most US senators. While it is most pleasing to see cell biology in the limelight, ES cells present the political elite in Washington with one of the thorniest ethical debates in recent history. The pro-life lobby is caught between its ethical convictions and an increasing realization that the US is loosing ground to stem cell boom countries such as South Korea.

Enter Senate majority leader Bill Frist. The staunch pro-lifer recently demonstrated a change of heart that was true to his medical background: in a milestone speech to the Senate on 29 July, he firmly rebuked president Bush's threat to veto H.R.810, a bill passed in the House by a large bipartisan majority that would lift the ban on federal funding for research on ES cells derived after the 2001 freeze on 22 cell lines. In particular, the bill would allow the use of ES cells derived from frozen embryos left over from fertility treatment. After consulting with several scientists, Frist accepted the medical promise of embryonic over adult stem cells and argued for disbanding with the stifling limitations imposed on research by the handful of lines that are all but useless for clinical work. Frist rightly argues that close oversight has to be guaranteed to prevent financial incentives and to clarify who decides the fate of the leftover embryos. The predicted outcome of Frist's speech is a broader swing of the Senate behind bill S.471 when it reconvenes this month, which may be sufficient to overturn president Bush's promised veto.

Support for the bill is important, but it does not solve the ongoing stalemate on somatic cell nuclear transfer. Others have proposed ethically more palatable ways around the issue of the sanctity of embryonic life. Notably, William Hurlbut, who serves on the President's Council on Bioethics, suggests 'altered nuclear transfer', in which mutations in developmentally relevant genes would prevent embryonic development past early stages sufficient to yield ES cells. While initially attractive, this concept is marred with problems such as how to find a gene appropriate for human development that will not interfere with any other aspects of biology, as well as the difficulty in defining a generally acceptable transition point at which an embryo acquires moral status (discussed in N. Engl. J. Med. 351, 2791). A more promising suggestion is the use of parthenogenesis, which has been shown to work in other primates. While alternatives should continue to be explored and a strong research focus on adult stem cells should be encouraged, it is important not to nip the nascent but promising science of ES cell research in the bud. Instead the focus should be on a truly global and enforceable ban on reproductive cloning (Nature Cell Biol. 7, 323; 2005).

S.471 is an important first step and cell biologists would do well to discuss the issues and alternatives openly with senators at every opportunity before their crucial vote on this and related bills in September.

View background material on Connotea: http://www.connotea.org/user/ bpulverer/tag/Embryonic\%20stem\%20cells.

\section{The web as originally intended}

When Tim Berners-Leecreated the web in the early 1990s atCERN, it was to enhance collaboration among geographically dispersed researchers. However, rather than a passive tool for information retrieval, the first browser was designed to allow one to readily post comments on what others had written. This original aim fell by the wayside and only recently gained momentum with editable web spaces such as blogs and wikis.

As cell biology continues to grow unabated it has matured into a truly globalized enterprise. Already it is next to impossible to keep up with the literature beyond ones most immediate research interests, and conferences remain an essential but inefficient means of prepublication information exchange. What is set to suffer most is exposure to serendipitous information - often it is the entirely unexpected that leads to the most dramatic conceptual advances.

With this in mind, Nature Publishing Group has just released a free online service called Connotea (http://www.connotea.org). This tool belongs to a new class of 'social bookmarking' applications that has already made its mark in the public domain with popular facilities such as Del.icio.us and Flickr. Connotea is tailored to the academic user; it facilitates bookmarking of any reference or URL and allows tagging with keywords. In essence, it is a more flexible form of traditional bookmarking, which should supplant endless alphabetical lists and folder-based archiving: tags provide the 'hooks' to retrieve information and allow for a given item to be assigned to more than one category. Importantly, any web page can be tagged - be it database records, news reports, research articles or lab homepages. At the same time, its ease of use is a distinct advantage over more traditional reference management systems (use the 'save this link' option provided on NCB papers).

While Connotea is useful for self-archiving, its main aim is to enhance communities through resource sharing. Cell biology is one of the more competitive arenas of biology and some may be reluctant to share what they are reading - especially a fortuitously found hidden gem that might lead to the next 'big thing. However, sharing your reading list is only pseudo-altruistic. The more you use Connotea, the more valuable it becomes: you will benefit from the many others posting their own reading material. However, in an effort to cater both for the community spirited and the self-archiver, all information can be either released in the public domain or kept private at will. Furthermore, you can create limited closed user groups to share information among a close circle or you can open access to a selected group of resources at a given time. One use of the latter facility is to point readers of an article you have written to source material - a sort of enhanced reference list. Finally, you can use this service to share information related to your lab, institute or a conference you are organizing. Connotea can also be usefully combined with RSS feeds, which allows you to keep abreast of changes made by others to specific Connotea tags - or indeed any website or blog.

Go become a web socialite and fulfil Berners-Lee's vision! 